\title{
High vs. low yielding oleoresin Pinus halepensis Mill. trees GC terpenoids profiling as diagnostic tool
}

\author{
Christoforos KARANIKAs ${ }^{1}$, Vincent WALKER ${ }^{2}$, Apostolos ScaltsoYiannes ${ }^{1}$, Gilles COMTE $^{2}$, \\ Cédric BERTRAND ${ }^{3 *}$ \\ ${ }^{1}$ Aristotle University of Thessaloniki, Department of Forestry and Natural Environment, Lab of Forest Genetics and Plant Breeding, \\ P.O. Box 238, 54124 Thessaloniki, Greece \\ ${ }^{2}$ Université de Lyon, Lyon 69003, France. Université Lyon 1, Villeurbanne 69622, France \\ CNRS, UMR 5557, Écologie Microbienne, Villeurbanne 69622, France \\ IFR 41, Lyon, Villeurbanne 69622, France \\ ${ }^{3}$ Université de Perpignan, Via Domitia, Laboratoire de Chimie des Biomolécules et de l'Environnement, EA 4215, 66860 Perpignan, France
}

(Received 29 July 2009; accepted 9 October 2009)

Keywords:

Pinus halepensis /

oleoresin /

GC-MS /

terpenoids

\begin{abstract}
- A discriminant study based on samples taken from high and low yielding oleoresin trees of two Greek populations, Chalkidiki and Euboia, was carried out. Oleoresin of Pinus halepensis Mill. was characterised by GC/MS analysis.

- The objectives of this study were: (i) to identify in detail the composition of the oleoresin of $P$. halepensis and in particular of high yielding trees (plus trees) (ii) to investigate a potential relationship between the oleoresin compounds and the oleoresin yield and (iii) to investigate any correlations among the compounds.

- About forty monoterpenes, sesquiterpenes and diterpenes were identified as main compounds representing $97.40 \%$ of the analyzed oleoresin. $\alpha$-Pinene, methyl abietate, abietic acid, palustric acid, isopimaric acid and neoabietic acid were the major compounds. Efficient discrimination was achieved between the two populations and between the two groups of trees (high and low yielding). In both cases, the differentiation was due to the quantitative variability of certain compounds. High positive correlations were found among certain compounds.

- The results suggest that the oleoresin profile is a useful tool for the discrimination of trees according to their provenance or their oleoresin yield.
\end{abstract}

Mots-clés :

Pinus halepensis /

oléorésine /

CG-SM /

terpènes
Résumé - Comparaison des oléorésines issues de pins (Pinus halepensis Mill.) à faible et haut rendement. Utilisation du profilage chromatographique des terpènoïdes comme outil de diagnostic.

- L'étude réalisée permet la discrimination d'arbres témoins et surproducteurs d'oléorésine de deux régions Grecques, la péninsule de Chalkidiki et l'île d'Eubée. L'oléorésine de Pinus halepensis Mill. est caractérisée par CG/SM.

- Les objectifs de cette étude sont de : (i) identifier les composés présent dans l'oléorésine et tout particulièrement dans les arbres surproducteur ; (ii) étudier l'existence d'une corrélation entre la surproduction d'oléorésine et sa composition et (iii) étudier les corrélations entre les niveaux de production des composés.

- Près de 40 monoterpènes, et diterpènes sont identifiés comme étant les principaux composés et représentent 97,40\% de l'oléorésine analysée. Les composés majoritaires sont l' $\alpha$-pinène, l'abietate de méthyle, les acides abiétique, palustrique, isopimarique et néoabiétique. Une discrimination efficace a été effectuée entre les deux populations et les deux groupes d'arbre (haut rendement - faible rendement). Dans les deux cas, la différenciation observée est due à la variabilité quantitative de certains composés. De fortes corrélations positives sont trouvées entre certains composés.

- Selon nos résultats le profilage chromatographique de l'oléorésine peut permettre de déterminer la provenance géographique et le niveau de production en oléorésine des arbres.

* Corresponding author: cedric.bertrand@univ-perp.fr 


\section{INTRODUCTION}

Oleoresin of coniferous trees is composed of turpentine (a mixture of monoterpenes $\left[\mathrm{C}_{10}\right]$, sesquiterpenes $\left[\mathrm{C}_{15}\right]$ ) and rosin (diterpene resin acids $\left[\mathrm{C}_{20}\right]$ ) and its main role is defensive. When a tree is wounded, the secretion of oleoresin seals the wound and creates a toxic environment for the invading insects and the associated fungal pathogens (Croteau and Johnson, 1985). Moreover, besides its ecological role, oleoresin's components are very important for industrial use. The volatile fraction, turpentine, is commonly used as paint thinner. Monoterpene and sesquiterpene flavour and fragrance agents are added to foods, beverages, perfumes, soaps, toothpaste, tobacco and other products (Verlet, 1993). For all the above reasons, oleoresin production is of great importance.

The oleoresin composition of many coniferous species has been reported in many studies. Most of the studies concerning terpenes investigate their potential role in the resistance or susceptibility of trees to attacks by diseases, insects and animals (Pureswaran et al., 2004; Schiller and Grunwald, 1987). Terpenes are also used in chemotaxonomy studies (Chang and Hanover, 1991; Lang, 1994) and identification of clones (Kossuth et al., 1988) because they are considered to be phytochemical markers. Critical to the use of terpenes as chemical markers is their stability and lack of sensitivity in the face of environmental factors (Hanover, 1992). Some exceptions in terpenes concentration can be found under extreme conditions like drought stress (Turtola et al., 2003) or nutrient availability (Muzika et al., 1989). Other studies investigate the large amounts of isoprenoids (isoprene and monoterpenes) emitted from plants, especially from trees, in the atmosphere. These compounds are called biogenic volatile organic compounds (VOCs) and they play an important role in the atmosphere chemistry.

One of the species with high oleoresin yield is Aleppo pine (Pinus halepensis Mill.). P. halepensis is one of the most widely distributed pine species in the Mediterranean region. It grows naturally from Morocco to Libya in North Africa, in eastern Spain, southern France, Italy, Adriatic cost, Greece and in the eastern Mediterranean from Israel to Jordan and Lebanon (Panetsos, 1999). In particular in Greece it is found in Peloponnese, the Ionian Islands, central Greece, Euboia, the Sporades islands and in the peninsula of Chalkidiki where the northern limit of its range is. The most important non-wood product of Aleppo pine is oleoresin.

Iconomou et al. (1964) and Mirov et al. (1966) studied the chemical composition of turpentine in the oleoresin of Aleppo pine and found that the major components are $\alpha$-pinene, camphene, $\beta$-pinene, myrcene, $\delta$-3-carene, limonene, $\beta$-phellandrene, $p$-cymene, $\gamma$-terpinene and terpinolene. Later, Schiller and Grunwald (1987) studied the xylem resin monoterpene composition as related to seed source and found that in spite of the wide range of the species, variation between seed sources is very low and only three distinct groupings - Greek, West European and North African - can be distinguished. The essential oil of Aleppo foliage was studied by many researchers (Dob et al., 2005) and apart from the monoterpenes, sesquiterpenes and diterpenes were also identi- fied. The composition of the essential oils from the needles, branches and female cones of $P$. halepensis were analysed (Macchioni et al., 2003) and, as in other species, (Pureswaran et al., 2004), differences in the quantity of the compounds were reported among the different tissues. Papajannopoulos et al. (2001) reported a detailed analysis of xylem oleoresin. Gallis and Panetsos (1997) used the composition of cortical oleoresin to discriminate individuals of $P$. halepensis, $P$. brutia and their hybrids.

Aleppo pine is presently tapped for commercial oleoresin production since this species is the most productive of all in the Greek territory. Among the trees tapped there is large variation in their yield. The average yield of Greek Aleppo pines is $2.7 \mathrm{~kg} / \mathrm{y}$ (Georgoulis, 1964) but there are some genotypes yielding more than $10 \mathrm{~kg} / \mathrm{y}$ (Moulalis, 1981). In the frame of this research we located these high yielding trees in two regions where tapping for commercial use is being practised. The objectives of this study were (i) to identify in detail the qualitative and quantitative composition of oleoresin of $P$. halepensis and in particular of high yielding trees (plus trees), (ii) to investigate a potential relationship between the oleoresin compounds and the oleoresin yield, and (iii) to investigate any correlations among the compounds. These trees can form the basis of a clone bank used as a source of future plus trees.

\section{MATERIALS AND METHODS}

\subsection{Sampling}

The sampled trees were located in two areas, Chalkidiki (Kassandra) and Euboia (Kirunthos). In each area, two groups of trees were selected according to their level of oleoresin production as ascertained during tapping in previous years. The first group (plus trees) consisted of trees yielding more than $12 \mathrm{~kg} / \mathrm{y}$, whereas the second (control trees) consisted of trees yielding less than $2 \mathrm{~kg} / \mathrm{y}$ (data not presented). In Chalkidiki 18 plus (17 kg average yield/y) and 13 control trees were selected among approximately 5000 trees, whereas in Euboia 11 plus (24 kg average yield/y) and 9 control trees were selected among approximately 10000 trees. All sampled trees were over 25 y old (mature trees).

Xylem oleoresin (samples) was obtained by wounding the tree without the use of chemical stimulants. On each selected tree, one hole $(50 \times 12 \mathrm{~mm})$ was made with a power drill, with a slight downwards slope. Each hole was drilled at the same height (breast height) and a tightly fitting glass vial was inserted and left from a few hours to one day to fill with resin (Fig. 1). Drilling that deep resulted in the collection of only xylem, and not bark oleoresin into the vial. Vials were hermitically closed and refrigerated until required for analysis (Latta et al., 2003). The use of glass vials during the oleoresin collection and the aftermath storage eliminated the volatile compounds' loss. Samples were taken on the 6th of August 2006 from Euboia and on the 12th of August 2006 from Chalkidiki.

\subsection{GC Analyses}

For qualitative analysis, $0.05 \mathrm{~g}$ of oleoresin were dissolved in $0.5 \mathrm{~mL}$ of methanol and in $50 \mu \mathrm{L}$ tetramethylammonium hydroxide used as methylation reagent. For quantitative analysis, exactly 


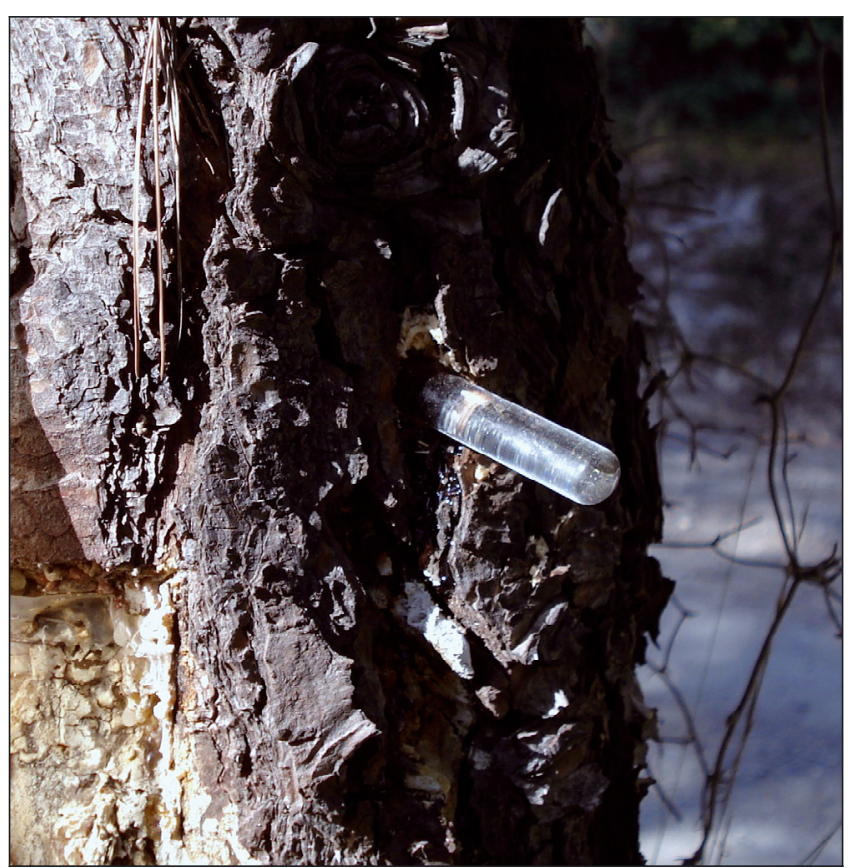

Figure 1. A glass vial full of oleoresin fitted with a slight downwards slope in a $P$. halepensis trunk. One hole was drilled at breast height on each selected tree.

$0.05 \mathrm{~g}$ of oleoresin were dissolved in $0.5 \mathrm{~mL}$ of methanol containing $1.2 \mathrm{mg}$ heptadecanoid acid and $2.5 \mu \mathrm{L}$ isobutylbenzene used as internal standards, as well as $50 \mu \mathrm{L}$ tetramethylammonium hydroxide used as methylation reagent (Arrabal et al., 2002, modified).

The GC-MS analyses were carried out using an HP 6890 gas chromatograph fitted with a HP-5 fused-silica column $(30 \mathrm{~m}, 0.25 \mathrm{~mm}$ i.d.; $0.25 \mu \mathrm{m}$ film thickness) coupled to a mass spectrometer (5973Hewlett-Packard). GC: oven temperature was programmed from 60 to $270{ }^{\circ} \mathrm{C}$ as follows: $60^{\circ} \mathrm{C}$ for $2 \mathrm{~min}$, rising with a $2^{\circ} \mathrm{C} / \mathrm{min}$ rate until $80{ }^{\circ} \mathrm{C}, 8{ }^{\circ} \mathrm{C} / \mathrm{min}$ rate until $200{ }^{\circ} \mathrm{C}$ and $2{ }^{\circ} \mathrm{C} /$ min rate until $270{ }^{\circ} \mathrm{C}$. Injector temperature was $260{ }^{\circ} \mathrm{C}$. The carrier gas was helium at a $1 \mathrm{~mL} / \mathrm{min}$ flow. The injection volume was $1 \mu \mathrm{L}$ with a split ratio 1:50. EI-MS: the electron energy was $70 \mathrm{eV}$. Ion source and the connection parts temperature was $290{ }^{\circ} \mathrm{C}$. Constituents were identified by comparing experimental retention indices with those of reference compounds run under identical conditions, laboratory's library and literature data (Adams, 2001) and by matching experimental fragmentation patterns in mass spectra with those of NIST98, Wiley 275 and CNRS libraries. The retention indexes (RI) were calculated using a homologous series of $n$-alkane and according to Kovats' formula (Kovats, 1958).

For quantitative measurements the same column was used under the same working conditions connected to a FID detector. The injection volume was $1 \mu \mathrm{L}$ with a split ratio $1: 25$, the nominal initial flow $1.0 \mathrm{~mL} / \mathrm{min}$ and the injector temperature $290{ }^{\circ} \mathrm{C}$. For the quantification of monoterpenes and sesquiterpenes isobutylbenzene was used as internal standard while for neutral diterpenes and resin acids the internal standard used was heptadecanoid acid. The concentration of each component is expressed as a percentage of the total amount of components.

\subsection{Statistical analysis}

The statistical analysis was carried out using the SPSS 13.0 statistical package. Average and standard deviations were calculated. Two statistical methods were applied to discriminate between plus and control tress and between Chalkidiki and Euboia trees. In each method a different approach is used since in one case (MannWhitney) each variable is tested separately while in the second (Discriminant Analysis) the variables are evaluated altogether.

The non-parametric Mann-Whitney test was performed to test for differences between the mean concentration of the variables. This test was performed in order to determine the statistical significance levels of the differences between means of each variable, considering groups by character plus or control trees independently of the populations and considering groups according to the provenance (populations) independently of their yield. The step-wise Discriminant Analysis was also carried out. In step-wise analysis the predictors (compounds) are entered sequentially based on their ability to discriminate between the groups. The method used was the Mahalanobis Distance procedure which maximizes a generalized measure of the distance between the two closest groups. The resulting group centroids are the mean values for the discriminant scores for a particular group. There is always an equal number of centroids and groups since there is one centroid for each group. For the discriminant analysis the data of the terpenes were $\log (x+1)$ transformed to fulfil the assumptions of the analysis (Turtola et al., 2003). Moreover, the Pearson correlations between the variables were calculated.

\section{RESULTS}

In Table I the qualitative and quantitative data of 40 monoterpenes, sesquiterpenes and diterpenes (including resin acids) are presented, expressed as percentages in both plus and control trees, sampled from Chalkidiki and Euboia. These concentrations represent $97.40 \%$ of the total quantity of analysed oleoresin. In particular, 11 monoterpenes, 12 sesquiterpenes and 17 diterpenes were identified. Resin acids were analysed as methyl esters (Arrabal et al., 2002; Lewinsohn et al., 1993). A preliminary analysis was conducted without any reactants and revealed that only one methyl ester in the oleoresin was methyl abietate (compound No. 39). The stationary phase used in this work could not separate methyl abietate from abietic acid (compound No. 39) due to diterpenes' methylation. The quantification of these compounds was made considering the sum of both.

No qualitative statistical significant differences were found between plus and control trees and between trees from Chalkidiki and Euboia. The average composition of the oleoresin was 30-38\% monoterpenes, 1.2-1.5\% sesquiterpenes and 60-69\% diterpenes. The highest concentrations among monoterpenes were of $\alpha$-pinene (28.73-35.84\%), myrcene $(0.34-0.55 \%)$ and limonene $(0.321-0.513 \%)$. The most abundant sesquiterpenes were $\beta$-copaene $(0.40-0.72 \%)$ and $\alpha$ muurolene $(0.23-0.46 \%)$, while the most abundant diterpenes were methyl abietate + abietic acid (36.87-41.28\%), palustric acid (9.40-10.09\%), isopimaric acid (4.69-6.94\%) and neoabietic acid $(4.75-5.70 \%)$.

The non-parametric Mann-Whitney test was performed between the plus and control trees from both areas and also 
Table I. Chemical composition of $P$. halepensis oleoresin. $\mathrm{X}=$ Chalkidiki plus trees, $\mathrm{SX}=$ Chalkidiki control trees, $\mathrm{E}=\mathrm{Euboia}$ plus trees, $\mathrm{SE}=$ Euboia control trees, $\mathrm{SD}=$ standard deviation, $\mathrm{RI}=$ retention index .

\begin{tabular}{|c|c|c|c|c|c|c|c|c|c|c|}
\hline & \multirow[b]{2}{*}{ Compounds } & \multirow[b]{2}{*}{ RI } & \multicolumn{4}{|c|}{ Chalkidiki } & \multicolumn{4}{|c|}{ Euboia } \\
\hline & & & $\mathrm{X}$ & SD & SX & $\mathrm{SD}$ & $\mathrm{E}$ & SD & SE & SD \\
\hline 2 & $\alpha$-pinene & 935 & 30.72 & 8.55 & 28.73 & 6.44 & 35.84 & 4.47 & 33.29 & 9.12 \\
\hline 3 & camphene & 945 & 0.23 & 0.07 & 0.21 & 0.07 & 0.27 & 0.04 & 0.23 & 0.10 \\
\hline 4 & sabinene & 970 & 0.02 & 0.07 & 0.00 & 0.01 & 0.01 & 0.01 & 0.01 & 0.01 \\
\hline 7 & 8-3-carene & 1012 & 0.48 & 1.78 & 0.08 & 0.09 & 0.37 & 0.72 & 0.25 & 0.33 \\
\hline 8 & limonene & 1032 & 0.42 & 0.55 & 0.32 & 0.22 & 0.51 & 0.38 & 0.44 & 0.51 \\
\hline 9 & cis- $\beta$-ocimene & 1042 & 0.01 & 0.01 & 0.01 & 0.01 & 0.02 & 0.01 & 0.01 & 0.01 \\
\hline 10 & $\gamma$-terpinene & 1061 & 0.02 & 0.02 & 0.01 & 0.00 & 0.01 & 0.00 & 0.03 & 0.03 \\
\hline 11 & $\alpha$-terpinolene & 1090 & 0.14 & 0.19 & 0.09 & 0.02 & 0.12 & 0.03 & 0.11 & 0.05 \\
\hline 15 & $\beta$-copaene & 1432 & 0.56 & 0.37 & 0.72 & 0.23 & 0.40 & 0.14 & 0.52 & 0.32 \\
\hline 16 & $\alpha$-humulene & 1467 & 0.10 & 0.06 & 0.12 & 0.04 & 0.07 & 0.02 & 0.09 & 0.06 \\
\hline 17 & D-germacrene & 1487 & 0.02 & 0.09 & 0.01 & 0.01 & 0.03 & 0.02 & 0.01 & 0.01 \\
\hline 18 & $\beta$-selinene & 1494 & 0.09 & 0.05 & 0.06 & 0.04 & 0.20 & 0.14 & 0.09 & 0.07 \\
\hline 19 & $\alpha$-muurolene & 1511 & 0.29 & 0.12 & 0.23 & 0.12 & 0.46 & 0.28 & 0.31 & 0.16 \\
\hline 20 & $\gamma$-cadinene & 1529 & 0.00 & 0.00 & 0.00 & 0.00 & 0.01 & 0.01 & 0.00 & 0.01 \\
\hline 21 & $\delta$-cadinene & 1534 & 0.04 & 0.02 & 0.03 & 0.02 & 0.06 & 0.04 & 0.04 & 0.03 \\
\hline 22 & $\alpha$-cadinol & 1658 & 0.01 & 0.01 & 0.01 & 0.01 & 0.02 & 0.01 & 0.01 & 0.01 \\
\hline 23 & $\alpha$-muurolol $=\delta$-cadinol & 1662 & 0.02 & 0.01 & 0.01 & 0.01 & 0.03 & 0.02 & 0.02 & 0.02 \\
\hline \multicolumn{11}{|c|}{ Diterpenes } \\
\hline 24 & abietadiene & 2106 & 0.06 & 0.09 & 0.04 & 0.01 & 0.04 & 0.01 & 0.04 & 0.04 \\
\hline 25 & $\begin{array}{l}\text { cyclohexanecarboxylic acid, } \\
\text { 1,3-dimethyl-2-[2-[3-(1- } \\
\text { methylethyl)phenyl]ethyl] }\end{array}$ & 2171 & 0.29 & 0.41 & 0.13 & 0.20 & 0.37 & 0.63 & 0.70 & 1.01 \\
\hline 31 & $\begin{array}{l}\text { Unresolved diterpene alde- } \\
\text { hyde } \mathrm{M}=286 \text {. }\end{array}$ & 2219 & 0.52 & 1.00 & 0.55 & 1.05 & 0.19 & 0.63 & 0.00 & 0.00 \\
\hline 32 & $\begin{array}{l}\text { Unresolved diterpene acid } \\
\text { methyl ester } \mathrm{M}=316 \text {. }\end{array}$ & 2242 & 0.05 & 0.03 & 0.05 & 0.02 & 0.06 & 0.03 & 0.05 & 0.04 \\
\hline 33 & unknown 2 & 2254 & 0.03 & 0.02 & 0.02 & 0.01 & 0.04 & 0.02 & 0.08 & 0.09 \\
\hline 34 & sandaracopimaric acid & 2272 & 0.99 & 0.51 & 1.23 & 0.24 & 0.52 & 0.19 & 0.90 & 0.53 \\
\hline 35 & isopimaric acid & 2318 & 5.87 & 1.86 & 6.94 & 1.35 & 4.69 & 1.77 & 6.34 & 2.30 \\
\hline 36 & palustric acid & 2328 & 9.57 & 1.57 & 10.09 & 1.25 & 9.40 & 0.77 & 9.57 & 1.96 \\
\hline 37 & dehydroabietic acid & 2346 & 0.86 & 0.47 & 0.85 & 0.29 & 0.61 & 0.11 & 1.66 & 1.02 \\
\hline 38 & 8,12 -Abietic acid & 2356 & 1.47 & 0.39 & 1.59 & 0.47 & 1.06 & 0.23 & 1.57 & 0.50 \\
\hline 39 & methyl abietate + abietic acid & 2416 & 39.93 & 6.67 & 41.28 & 4.66 & 38.62 & 3.20 & 36.87 & 11.82 \\
\hline \multirow[t]{4}{*}{40} & neoabietic acid & 2461 & 5.71 & 1.23 & 5.52 & 0.95 & 4.75 & 0.64 & 5.61 & 2.02 \\
\hline & Monoterpenes \% & & 32.90 & 11.62 & 30.07 & 7.24 & 38.07 & 6.08 & 35.16 & 10.62 \\
\hline & Sesquiterpenes $\%$ & & 1.26 & 0.70 & 1.29 & 0.51 & 1.48 & 0.80 & 1.22 & 0.78 \\
\hline & Diterpenes\% & & 65.84 & 15.27 & 68.64 & 11.2 & 60.46 & 8.32 & 63.61 & 21.72 \\
\hline
\end{tabular}




\section{Canonical Discriminant Functions}

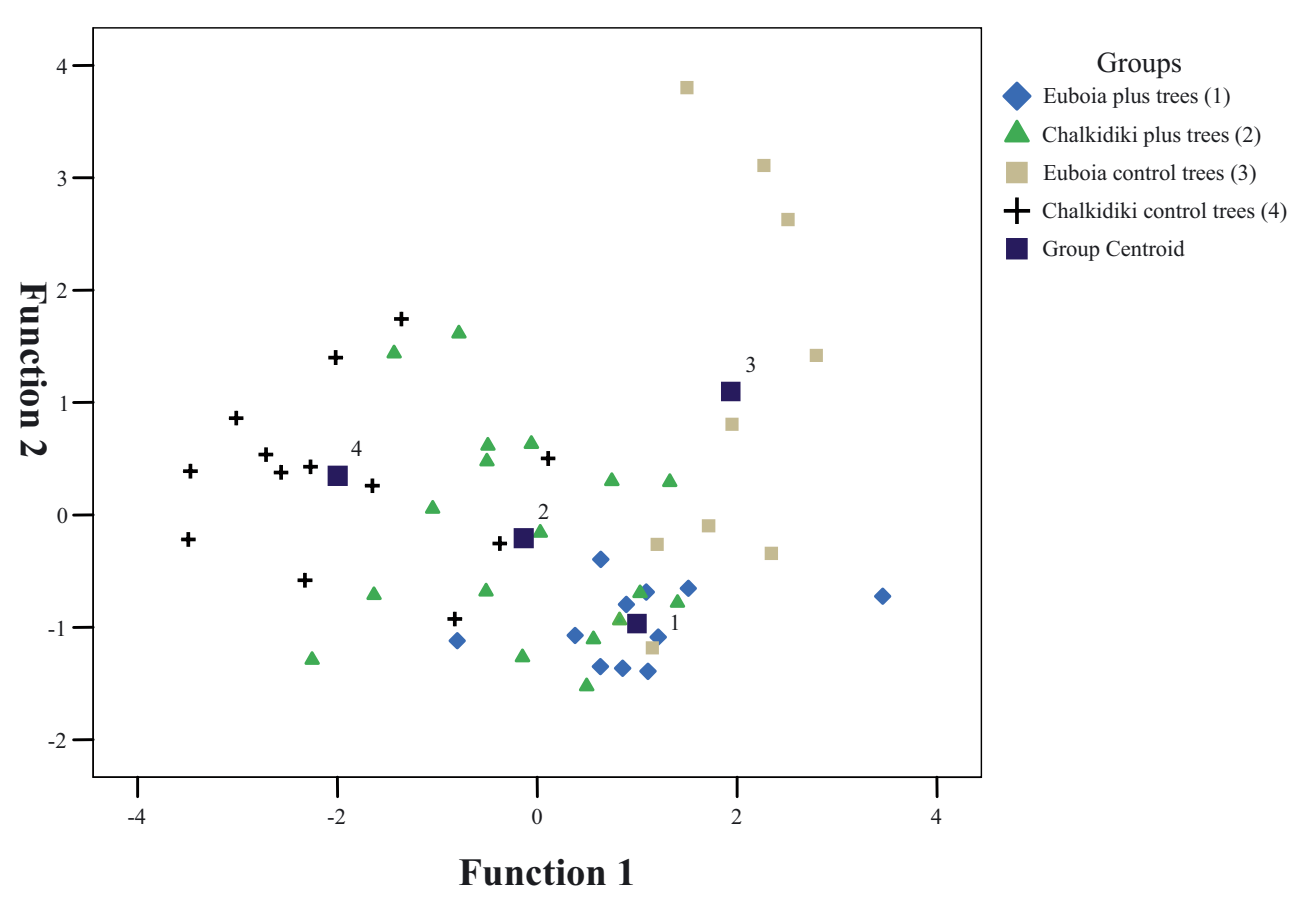

Figure 2. Discriminant analysis of the terpenic composition. Euboia plus trees (1), Chalkidiki plus trees (2), Euboia control trees (3), Chalkidiki control trees (4), Group Centroid (ם).

between the trees of each population independently of their yield. In the first case, 10 compounds were found to differentiate the groups according to their oleoresin production (plus and control trees) which were: sabinene $(p=0.039), \beta$-pinene $(p=0.040)$, myrcene $(p=0.009)$, cis- $\beta$-ocimene $(p=0.012)$, $\gamma$-terpinene $(p=0.007), \beta$-selinene $(p=0.019)$, sandaracopimaric acid $(p=0.035)$, isopimaric acid $(p=0.011)$, dehydroabietic acid $(p=0.006)$ and abietic acid $(p=0.046)$ at $5 \%$ significance. In the second case, the compounds that differentiate the two populations were: $\alpha$-pinene $(p=0.025)$, sabinene $(p=0.043), \beta$-pinene $(p=0.038)$, cis- $\beta$-ocimene $(p=0.017), \alpha$-terpinolene $(p=0.019), \beta$-copaene $(p=$ $0.039), \alpha$-humulene $(p=0.033), \gamma$-cadinene $(p=0.009)$, $\alpha$-cadinol $(p=0.032)$, unknown1 $(p=0.027)$, secodehydroabietic acid $(p=0.025)$, unknown $2(p=0.001)$, sandaracopimaric acid $(p=0.003)$, abietic acid $(p=0.032)$ at $5 \%$ significance level. Moreover, five compounds were found to differentiate both plus from control trees and trees from the two populations: sabinene, $\beta$-pinene, $c i s-\beta$-ocimene, sandaracopimaric acid and abietic acid.

The step-wise discriminant analysis resulted in two canonical discriminant functions with 0.821 and 0.577 canonical correlations respectively (Fig. 2). Altogether, the groups of trees were discriminated by 6 compounds: sandaracopimaric acid, $\gamma$-terpinene, cyclohexanecarboxylic acid, $\beta$-copaene, neoabietic acid and dehydroabietic acid. The first two functions explain $97.6 \%$ of the variance. The total correct classification result was $72.5 \%$. More specifically, the correct classification result was $81.8 \%$ for the plus trees from Euboia, $55.6 \%$ for the plus trees from Chalkidiki, $88.9 \%$ for the control trees from Euboia and $76.9 \%$ for the control trees from Chalkidiki (Tab. II).

Figure 2 shows that the discrimination of the two populations (Euboia and Chalkidiki) is affected by Function 1 because trees from Euboia are located on the right side of the plot, while trees from Chalkidiki are located at the central and left part. Since Function 1 is associated with cyclohexanecarboxylic acid, we can conclude that this compound helps us to classify trees according to their origin (provenance). Similarly, the discrimination of the trees according to their yield is achieved with Function 2 which is strongly associated with dehydroabietic acid, $\gamma$-terpinene and $\beta$-copaene. The high yielding trees (plus trees) are located at the lower part of the plot, while the control trees are located at the central and upper part.

The correlations for all the pairs of variables were calculated. The Pearson correlations with $r>0.80$ and $p$ value $<0.001$ are presented in Table III. Altogether, 46 correlations are presented, from which 6 are found among the monoterpenes, 39 among the sesquiterpenes and 1 among the diterpenes. More than half of the monoterpenes $(54.55 \%)$ were highly correlated with one or more monoterpenes, while just two diterpenes $(11.76 \%)$ were highly correlated with each other. On the other hand, all sesquiterpenes (100\%) exhibited high correlations with one or more sesquiterpenes. The strong correlations among these compounds might indicate 
Table II. Classification table. Trees are classified to their groups according to the prediction of the model produced from the discriminant analysis. $\mathrm{E}=$ Euboia plus trees, $\mathrm{X}=$ Chalkidiki plus trees, $\mathrm{SE}=$ Euboia control trees, $\mathrm{SX}=$ Chalkidiki control trees.

\begin{tabular}{|c|c|c|c|c|c|c|}
\hline & \multirow{2}{*}{ Groups } & \multicolumn{4}{|c|}{ Predicted group membership $^{a}$} & \multirow{2}{*}{ Total } \\
\hline & & $\mathrm{E}$ & $\mathrm{X}$ & SE & SX & \\
\hline \multirow{4}{*}{ Original count } & $\mathrm{E}$ & 9 & 2 & 0 & 0 & 11 \\
\hline & $X$ & 4 & 10 & 0 & 4 & 18 \\
\hline & SE & 1 & 0 & 8 & 0 & 9 \\
\hline & SX & 0 & 3 & 0 & 10 & 13 \\
\hline \multirow{4}{*}{$\%$} & $\mathrm{E}$ & 81.8 & 18.2 & 0 & 0 & 100.0 \\
\hline & $\mathrm{X}$ & 22.2 & 55.6 & 0 & 22.2 & 100.0 \\
\hline & SE & 11.1 & 0 & 88.9 & 0 & 100.0 \\
\hline & SX & 0 & 23.1 & 0 & 76.9 & 100.0 \\
\hline
\end{tabular}

${ }^{a} 72.5 \%$ of original grouped cases correctly classified.

Table III. Highly correlated compounds in P. halepensis oleoresin, $p<0.001$.

\begin{tabular}{lccccc}
\hline Correlated & Compounds & Pearson $r$ & Correlated & Compounds & Pearson $r$ \\
\hline$\alpha$-pinene & tricyclene & 0.948 & d-germacrene & $\alpha$-cadinol & 0.954 \\
$\alpha$-pinene & camphene & 0.880 & $d$-germacrene & $\alpha$-muurolol & 0.980 \\
camphene & tricyclene & 0.851 & $\beta$-selinene & $\beta$-elemene & 0.883 \\
sabinene & 3 - $\delta$-carene & 0.957 & $\beta$-selinene & $\alpha$-copaene & 0.884 \\
sabinene & $\alpha$-terpinolene & 0.986 & $\beta$-selinene & $\alpha$-muurolene & 0.925 \\
3 - $\delta$-carene & $\alpha$-terpinolene & 0.943 & $\beta$-selinene & $\delta$-cadinene & 0.907 \\
$\alpha$-cadinol & cis- $\beta$-ocimene & 0.845 & $\beta$-selinene & $\alpha$-cadinol & 0.864 \\
$\alpha$-cadinol & $\alpha$-muurolol & 0.941 & $\beta$-selinene & $\alpha$-muurolol & 0.895 \\
$\alpha$-copaene & $\beta$-elemene & 0.919 & $\alpha$-muurolene & $\delta$-cadinene & 0.978 \\
$\alpha$-copaene & $\alpha$-muurolene & 0.966 & $\alpha$-muurolene & $\alpha$-cadinol & 0.947 \\
$\alpha$-copaene & $\delta$-cadinene & 0.964 & $\alpha$-muurolene & $\alpha$-muurolol & 0.965 \\
$\alpha$-copaene & $\alpha$-cadinol & 0.925 & cyclosativene & $\alpha$-copaene & 0.968 \\
$\alpha$-copaene & $\alpha$-muurolol & 0.950 & cyclosativene & $\beta$-elemene & 0.960 \\
$\beta$-elemene & $\alpha$-germacrene & 0.939 & cyclosativene & $\alpha$-germacrene & 0.977 \\
$\beta$-elemene & $\alpha$-muurolene & 0.929 & cyclosativene & $\beta$-selinene & 0.911 \\
$\beta$-elemene & $\delta$-cadinene & 0.957 & cyclosativene & $\alpha$-muurolene & 0.985 \\
$\beta$-elemene & $\alpha$-cadinol & 0.890 & cyclosativene & $\delta$-cadinene & 0.990 \\
$\beta$-elemene & $\alpha$-muurolol & 0.949 & cyclosativene & $\alpha$-cadinol & 0.948 \\
$d$-germacrene & $\beta$-selinene & 0.899 & cyclosativene & $\alpha$-muurolol & 0.974 \\
d-germacrene & $\alpha$-copaene & 0.952 & $\delta$-cadinene & $\alpha$-cadinol & 0.942 \\
$\alpha$-germacrene & $\beta$-elemene & 0.939 & $\delta$-cadinene & $\alpha$-muurolol & 0.971 \\
$d$-germacrene & $\alpha$-muurolene & 0.967 & $\alpha$-humulene & $\beta$-copaene & 0.999 \\
$d$-germacrene & $\delta$-cadinene & 0.973 & secodehydroabietic acid & Unknown1 & 0.898 \\
\hline
\end{tabular}

a common precursor. In Figure 3 two illustrative regression equations and plots are presented.

\section{DISCUSSION}

The method followed in this study for the analysis of xylem oleoresin was quite satisfactory since 40 compounds were identified simultaneously. In most of the reported studies, only the volatile fraction was studied. Previous analyses of oleoresin from Greek populations reported 8 (Iconomou et al., 1964; Mirov et al., 1966), 12 (Schiller and Grunwald, 1987) and 7 (Papajannopoulos et al., 2001) monoterpenes. In all these cases the first identified compound (smaller RI) was $\alpha$ pinene in contrast with the present study where the first compound is tricyclene. Moreover, in the above studies, sabinene, which is the fourth (according to RI) identified compound in this study, wasn't found. These two compounds, tricyclene and sabinene, were reported only by Macchioni et al. (2003) who, however, analysed the essential oil composition of needles, branches and female cones of $P$. halepensis and not xylem oleoresin.

Xylem rosin (non-volatile fraction) composition of $P$. halepensis from Greek populations is only reported in one study (Papajannopoulos et al., 2001) where the number of trees sampled was limited. Papajannopoulos et al. found 14 compounds whereas in the present study 17 compounds are reported. Nevertheless, the qualitative composition of rosin between the two studies is quite similar.

In the present study the three compounds among monoterpenes with the highest concentrations are in descending order: $\alpha$-pinene, myrcene and limonene. The three major monoterpenes found by Iconomou et al. (1964), for a population from Chalkidiki, were $\alpha$-pinene, limonene and camphene and by 


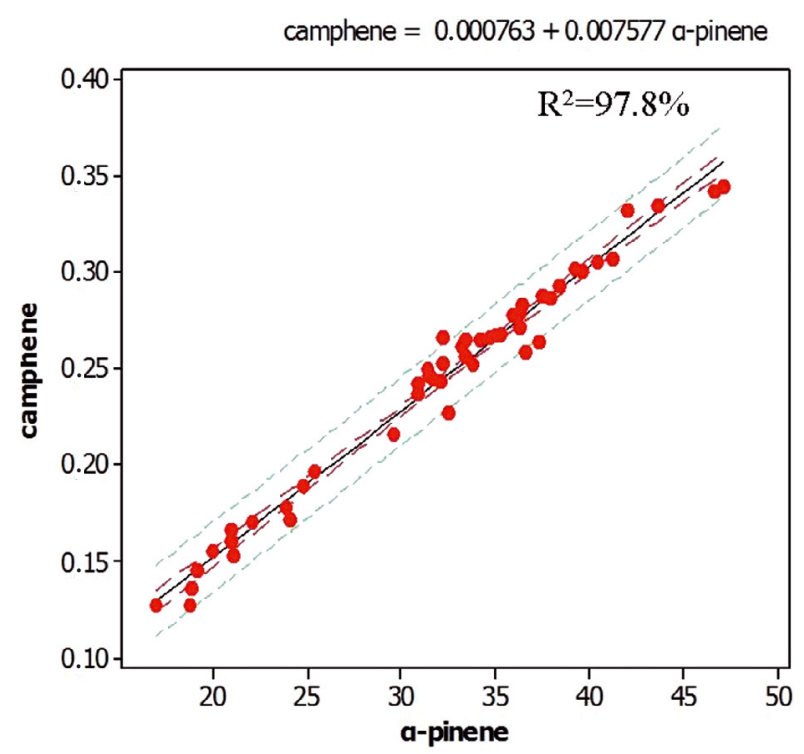

* 2 outliers were excluded from the regression analysis.

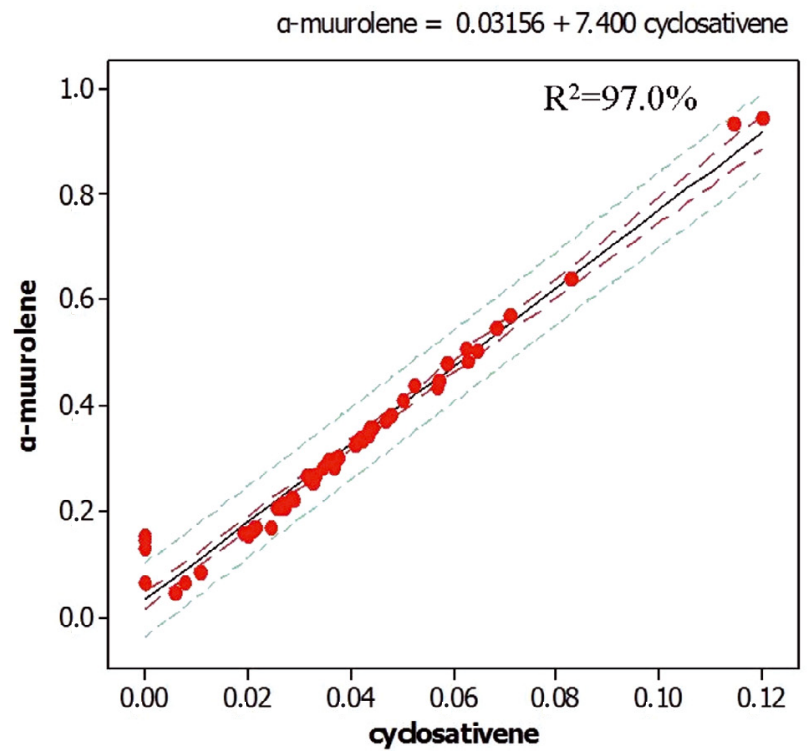

Figure 3. Regression plots between $\alpha$-pinene and camphene (monoterpenes)* and $\alpha$-muurolene and cyclosativene (sesquiterpenes). The correlation coefficients $R^{2}$ and the regression equations are shown in the plots. The correlation coefficient $\left(R^{2}\right)$ is defined as the square of the Pearsons correlation coefficient $r$.

Schiller and Grunwald (1987), for a population from Euboia, were $\alpha$-pinene, 3 -carene and myrcene. Papajannopoulos et al. (2001) found $\alpha$-pinene, myrcene and camphene/ $\beta$-pinene as the three major monoterpenes. In all cases, $\alpha$-pinene is the most abundant compound among monoterpenes along with myrcene which is also found in large quantities. With regard to the quantities of xylem oleoresin diterpenes of Aleppo pine, Papajannopoulos et al. (2001) reported palustric/levopimaric acid, abietic acid, neoabietic acid and isopimaric acid as the four major compounds, which is also confirmed by the results of the present study.

The Mann-Whitney tests indicate that the differentiation between plus and control trees is established at 5\% significance level by 10 compounds: 5 monoterpenes, 1 sesquiterpene and 4 diterpenes. At $1 \%$ significance level, the discrimination is achieved by three compounds: myrcene, $\gamma$-terpinene and dehydroabietic acid. Two of them, myrcene and dehydroabietic acid also discriminate plus from control trees in P. pinaster (Arrabal et al., 2002). Similarly, the two populations (Chalkidiki and Euboia) are distinguished by 14 compounds: 5 monoterpenes, 4 sesquiterpenes and 5 diterpenes. Among them, $\alpha$-pinene is also reported by Arrabal et al. (2005) to differentiate two provenances of $P$. pinaster.

The step-wise discriminant analysis is quite efficient in discriminating plus from control trees despite the limited number of the samples. In particular, the resulted discrimination is more efficient than that observed by Arrabal et al. (2002) who reported a tendency to separate plus from control trees using only the diterpenes' concentrations while such a tendency wasn't reported for the monoterpenes' concentrations. With regard to provenances separation, this analysis is again more efficient than that of a previous study (Arrabal et al., 2005) where only certain groups of five Spanish provenances of $P$. pinaster were discriminated and not all of them. Furthermore, the discriminant analysis establishes a quite reliable model for future classification of trees, from Euboia and Chalkidiki, according to their oleoresin yield. The inclusion of new cases in the classification model increases its effectiveness.

The high correlations among compounds appear only within the same class of terpenes. Especially, all the sesquiterpenes are highly correlated with each other. There are also many low or moderate negative correlations between monoterpenes and diterpenes (data not shown). Strong correlations between two monoterpenes, $\alpha$-pinene and camphene, were also found by Sjödin et al. (2000) in Norway Spruce and Fäldt et al. (2001) in six Pinus species (not including P. halepensis). Hiltunen and Laakso (1995) and Wise and Croteau (1999) suggested that these strong correlations might indicate a common precursor. On the other hand, Fäldt et al. (2001) reported a strong correlation between $\alpha$ - and $\beta$-pinene which was not found in the present analysis of $P$. halepensis.

Conclusively, the qualitative and quantitative composition of $P$. halepensis oleoresin reported in this study is in general similar to that reported in previous studies. This "metabolite fingerprinting" approach of terpenoids is a good tool for Pinus discrimination. Certain compounds show statistical significant different concentrations between high and low yielding trees, as well as between the two provenances. A model is established, through discriminant analysis, which can help in future classification of trees with unknown oleoresin yield. The strong correlations between certain compounds, especially between the sesquiterpenes, might indicate a common precursor for these compounds. The selected high-yielding trees can be used in the establishment of a clone bank for future plus trees. 
Acknowledgements: The authors are particularly grateful to $\mathrm{Pr}$. René Rohr, UMR 5557, University Lyon 1, for his help in project management.

\section{REFERENCES}

Adams R.P., 2001. Identification of essential oil components by gas chromatogratography/quadropole mass spectroscopy. Allured Publishing Corporation, Illinois, $455 \mathrm{p}$.

Arrabal C., Cortijo M., De Simón B.F., García-Vallejo M.C., and Cadahía E., 2002. Pinus pinaster oleoresin in plus trees. Holzforschung 56 : 261-266

Arrabal C., Cortijo M., de Simon B.F., Garcia-Vallejo M.C., and Cadahia E., 2005. Differentiation among five Spanish Pinus pinaster provenances based on its oleoresin terpenic composition. Biochem. Syst. Ecol. 33: 1007-1016.

Chang J. and Hanover J.W., 1991. Geographic variation in the monoterpene composition of black spruce. Can. J. For. Res. 21: 1796-1800.

Croteau R. and Johnson M.A., 1985. Biosynthesis of terpenoid wood extractives. In: Higuchi T. (Ed.), Biosynthesis and Biodegradation of wood components, Academic Press, Orlando, FL, pp. 379-439.

Dob T., Berramdane T., and Chelgoum C., 2005. Chemical composition of essential oil of Pinus halepensis Miller growing in Algeria. C. R. Chimie 8: 1939-1945.

Fäldt J., Sjödin K., Persson M., Valterova I., and Borg-Karlson A.K., 2001. Correlations between selected monoterpene hydrocarbons in the xylem of six Pinus (Pinaceae) species. Chemoecology 11: 97106.

Gallis A.T. and Panetsos K.P., 1997. Use of cortical terpenes to discriminate Pinus brutia (Ten.), Pinus halepensis (Mill.) and their hybrids. Silvae Genet. 46: 82-88.

Georgoulis E.B., 1964. Cultivation of Aleppo pine, together with evergreen hardwoods and positive influence on gum yield in composite forest. For. Res. Inst., No. 11, Athens.

Hanover J.W., 1992. Applications of terpene analysis in forest genetics. New Forests 6: 159-178.

Hiltunen R. and Laakso I., 1995. Gas chromatographic analysis and biogenetic relationships of monoterpene enantiomers in Scots pine and juniper needle oils. Flavour Fragr. J. 10: 203-210.

Iconomou N., Valkanas G., and Büchi J., 1964. Composition of gum turpentines of Pinus halepensis and Pinus brutia grown in Greece. J. Chromatog. 19: 29-33.

Kossuth S.V., McCall E., and Ledbetter J., 1988. Clone certification by use of cortical monoterpenes as biochemical markers. Silvae Genet. 37: $73-76$

Kovats E., 1958. Gas chromatographische Charakteriserung organischer Verbindungen. I. Retentions indices aliphatischer halogenide, alkohole, aldehyde und ketone. Helv. Chim. Acta 41: 1915-1932.
Lang K.J., 1994. Abies alba Mill.: Differentiation of provenances and provenance groups by the monoterpene patterns in the cortex resin of twigs. Biochem. System. Ecol. 22: 53-63.

Latta R.G., Linhart Y.B., Snyder M.A., and Lundquist L., 2003. Patterns of variation and correlation in the monoterpene composition of xylem oleoresin within populations of ponderosa pine. Biochem. System. Ecol. 31: 451-465.

Lewinsohn E., Savage T.J., Gijzen M., and Croteau R., 1993. Simultaneous analysis of monoterpenes and diterpenoids of conifer oleoresin. Phytochem. Anal. 4: 220-225.

Macchioni F., Cioni P.L., Flamini G., Morelli I., Maccioni S., and Ansaldi M., 2003. Chemical composition of essential oil from needles, branches and cones of Pinus pinea, P. halepensis, P. pinaster and P. nigra from central Italy. Flavour Fragr. J. 18: 139-143.

Mirov N.T., Zavarin E., and Snajberk K., 1966. Chemical composition of the turpentines of some eastern Mediterranean pines in relation to their classification. Phytochem. 5: 97-102.

Moulalis D., 1981. Variation of resin yield of Pinus halepensis in Kassandra Chalkidiki. Scientific Annals of the School Agriculture and Forestry, Vol. 24 - Annex (in Greek, English abstract).

Muzika R.M., Pregitzer K.S., and Hanover J.W., 1989. Changes in terpene production following nitrogen fertilization of grand fir (Abies grandis Dougl.) seedlings. Oecologia 80: 485-489.

Panetsos K.P., 1999. Pinus halepensis (Mill.) Enzyklopädie der Holzgewächse 18 (III-1), 10 p.

Papajannopoulos A.D., Song Z.Q., Liang Z.Q., and Spanos J.A., 2001. GC-MS analysis of oleorein of three Greek pine species. Holz RohWerkst. 59: 443-446.

Pureswaran D.S., Gries R., and Borden J.H., 2004. Quantitative variation in monoterpenes in four species of conifers. Biochem. System. Ecol. 32: 1109-1136.

Schiller G. and Grunwald C., 1987. Resin monoterpenes in range-wide provenance trials of Pinus halepensis Mill. in Israel. Silvae Genet. 36: 109-114.

Sjödin K., Persson M., Fäldt J., Ekberg I., and Borg-Karlson A.K., 2000. Occurrence and correlations among monoterpene hydrocarbons in Picea abies and Pinus sylvestris. J. Chem. Ecol. 26: 1701-1720.

Turtola S., Manninen A.M., Rikala R., and Kainulainen P., 2003. Drought stress alters the concentration of wood terpenoids in Scots pine and Norway spruce seedlings. J. Chem. Ecol. 29: 1981-1995.

Verlet N., 1993. Commercial aspects, Volatile Oil Crops: Their Biology Biochemistry and Production. In: Hay R.K.M. and Waterman P.G. (Eds.), Longman Scientific and Technical, Essex, UK, pp. 137-174.

Wise M.L. and Croteau R., 1999. Monoterpene biosynthesis. In: Cane D.E. (Ed.), Comprehensive natural products chemistry: 2. Isoprenoids including carotenoids and steroids, Pergamon, Oxford, pp. $97-153$. 